\title{
Egdūnas Račius*
}

Generolo Jono Žemaičio Lietuvos karo akademija

\section{Islamiška khilafos valstybė kaip post-/antinacionalinis valstybinis darinys: kintančios piliečio ir tautos sampratos iššūkiai Europai}

\begin{abstract}
Vakarų ịprastiniame diskurse „užsienio kovotojais“ dažnai laikomi žmonès, per pastaruosius penkerius metus apsigyvenę Vakarų Azijoje. Nors iš tiesų nemaža jų dalis prisijungẻ prie ịvairių ginkluotų grupuočių, tačiau dauguma, pavyzdžiui, su tèvais keliaujantys vaikai ir jaunos moterys - Vakarų valstybėse vyraujančiu populiariu žargonu menkinamai pavadintos "džihado nuotakomis“ - netapo arba net negalèjo tapti šių grupių dalimi. Tačiau, nekalbant apie šias kategorijas, tikètina, kad ì ginkluotas grupuotes Sirijoje ir Irake įstoję jauni žmonès, kurie gali būti tapatinami su „kovotojais“, nèra „užsieniečiai“ (ir tikrai didžioji jų dalis savęs tokiais nelaiko). Didžiulis skaičius ị Vakarų Aziją nuvažiavusių žmonių i̇siliejo ị Islamišką khilafos valstybę (IKV), kurioje jų statusas panašus í „natūralizuotų piliečìų", kurių natūralizacijos procesas yra susijęs su ịstojimu į IKV ginkluotąsias pajègas. Žmonès, kurie neịstojo arba negalèjo įstoti ị IKV ginkluotąsias pajègas, tapo piliečiais, prisiekusiais ištikimybę kalifui (Abū Bakr al-Baghdadi) ir atlikusiais vadinamąją priverstinę hidžrą - išsikèlimą iš netikinčiųjų šalies ị paskelbto kalifato vadovaujamą islamo šali. „Islamo valstybès“ (toliau - IV) inicijuotas kalifato projektas yra unikalus reiškinys ne tik tarptautinių santykių teorijos, bet ir klasikinių valstybės formavimosi ir nacijos / nacionalinès savimonès kūrimo sampratų atžvilgiu ir atskleidžia naują požiūrị i pilietybès suvokimą. Tiek siaurąja karinio saugumo, tiek bendrąja valstybių prasme jis kelia naujus iššǔkius ypač toms šalims (tarp jų ir Europos), kurių piliečiai atsisako savo pradinio socialinio kontrakto kurdami naują.
\end{abstract}

\section{Ivadas}

Naujos valstybès atsiradimas vietoj buvusios arba jos formavimasis kaip dalies, atsiskyrusios nuo egzistuojančios šalies, yra ịprastas reiškinys. XX amžiaus paskutiniame dešimtmetyje (iš naujo) atsirado daugiau nei dešimt nepriklausomų valstybių Europoje ir dešimt savarankiškų valstybių kitose pasaulio šalyse. Šias šalis sieja jų prigimtis - jos yra nacionalinès valstybès ${ }^{1}$, daugeliu

\footnotetext{
"Dr. Egdūnas Račius yra Lietuvos karo akademijos Politikos mokslų katedros profesorius. Adresas korespondencijai: Šilo 5A, 10322 Vilnius; tel. (8 5) 210 3582; el. p.: raciusegdunas@gmail.com ${ }^{1}$ Opello W.C., Rosow S.J. (2004) The Nation-State and Global Order: A Historical Introduction to Contemporary Politics, Second edition, Lynne Rienner Publishers.
} 
atvejų vadinamos titulinių etninių grupių valstybėmis. Kitaip tariant, suverenitetą igijusios etninès grupès virsdavo tautomis. Žinoma, naujai susiformavusios valstybės nèra vienatautės; jų valstybingumo ir nacijos naratyvas remiasi titulinių etninių grupių istorijų pasakojimo sistema.

2014 m. netikètai nustebino pasauli tuo, kad atsirado naujas teritorinis vienetas - IKV (arabuc kalboje - dawla al-khilafa al-islamiyya), kuris pareiške teisę i valstybingumą, savo oficialiame pavadinime vartodamas net du valstybės statusą patvirtinančius žodžius, ir kuris toli gražu neatitinka nacionalinès valstybès klasikinès sampratos. Pavadinime pirmasis žodis dawla, iš literatūrinès arabų kalbos verčiamas kaip „valstybe்“ (šiuolaikinis standartinis terminas), yra visiškai priimtinas ir neverčiantis nustebti. Kai kurios arabų šalys šị žodị vartoja savo oficialiuose pavadinimuose, pavyzdžiui, Kuveito Valstybė, Kataro Valstybė. Kitas žodis khilafa kelia nuostabą, nes tai yra klasikinis terminas ${ }^{2}$, laisvai verčiamas kaip „patikètinystë“. Užtikrinant, kad naujas darinys visiškai skirtųsi nuo kitų šiuolaikinių valstybių, jo steigejjų buvo pridètas žodis „islamo“. Tai nèra išimtis net ir tarp šiomis dienomis egzistuojančių valstybių, pavyzdžiui, prisiminkime Irano Islamo Respubliką, Afganistano Islamo Respubliką, Mauritanijos Islamo Respubliką. Taigi anksčiau minètame pavadinime ypatingą dèmesị derètų skirti gimstančio valstybinio darinio pretenzijai i „patikètinystę“.

Šiuo straipsniu nesiekiama išanalizuoti, juo labiau kritiškai išnagrinèti šios „patikètinystès“ sąvokos, ịteisinti IKV pretenzijų $\mathfrak{i}$ "patikètinystę" arba jas atmesti, bet siekiama nustatyti, kokiu būdu IKV atsiradimas ir įsitvirtinimas turejo ịtakos ir iš tiesų praplètè „piliečio“ („pilietybès“) ir „nacijos“ („naciškumo“) sampratas naujų valstybių, tokių kaip IKV, neatitinkančių nacionalinės valstybės apibrèžimo, formavimosi kontekste. Nors šis pokytis, be abejonės, gali būti laikomas galiojančiu tik IKV, tačiau drịsčiau pritaikyti jị visam pasauliui, ypač Europai, kurios tūkstančiai gyventojų nusprendè atsisakyti pradinio socialinio kontrakto IKV labui. Emigracija (jų laikoma šventa pareiga hidžra) yra tik men$\mathrm{ka}$ dalis iššūkio, išplaukiančio iš piliečio ir jo priklausymo nacijai pasikeitusio suvokimo. IKV piliečių grị̌tamoji migracija ị Europą, pasaulio galybėms išardžius IKV, yra kitas didesnis iššūkis, jei ne grèsmè. Taigi šiame straipsnyje bus ne tik nagrinejjamas kintantis „piliečio“ ir „nacijos“ suvokimas IKV susikūrimo išdavoje, bet ir bus bandoma ižžvelgti, kokius iššūkius šis pokytis atnešè būtent IKV kaip valstybinio darinio neišvengiamos pražūties akivaizdoje.

Taip pat šiuo straipsniu ketinama mesti iššūki populiariam, žmonių sąmonèje įsišaknijusiam hegemoniniam diskursui, kai IKV laikoma neturinčia

\footnotetext{
${ }^{2}$ Kennedy H. (2016) Caliphate: The History of an Idea, Basic Books.
} 
valstybingumo (ir naciškumo) vizijos teroristų grupe ${ }^{3}$, „užsienio kovotojus“ iš „teroristų“ paverčiant (natūralizuotais) „piliečiais“. Autorius anaiptol neketina pripažinti IKV teisètu pagrindu susiformavusia valstybe, bet siekia pažvelgti i IKV per nenormatyvinę prizmę, t. y. fenomenologiškai ir be išorinio poveikio ar išankstinių nuostatų. Tokiu būdu galima ne tik giliau ir plačiau suprasti daugybę su anksčiau minètu reiškiniu susijusių procesų, tarp kurių ne mažiau svarbi yra trečiųjų šalių piliečių migracija ị IKV, bet ir praturtinti pilietybės, natūralizacijos ir nacijos kūrimo sampratų teorijas. Beje, IKV žlugus ir praradus teritorinio vieneto statusą, jos ideologija ir ja paremta vizija beveik neabejotinai pritrauks pasekejjų iš kitų pasaulio šalių ir vèl pavers kai kuriuos IKV gyvenančius piliečius "migrantais“ (muhadžirūn). Kitaip tariant, IKV ideologija tikrai išlaikys ją kaip valstybės projektą, kurio ideologinių aspektų analizė išliks aktuali net sunaikinus IKV.

\section{Islamiška khilafos valstybė kaip... valstybė}

Nors čia nagrinejjamas teritorinis vienetas yra gana trumpalaikis reiškinys - IKV formaliai atsirado $2014 \mathrm{~m}$. vasarą ir egzistavo mažiau nei trejus metus (straipsnis buvo rašomas $2017 \mathrm{~m}$. vasarị; tuo metu IKV didžiausias miestas Mosulas jau buvo apgultas koalicijos prieš IKV ir buvo rengiamasi atakuoti jos sostinę Raką) - jo istorija yra kur kas ilgesnè. Jo atsiradimas siejamas su drąsiu bandymu pirmojo šio amžiaus dešimtmečio viduryje sukurti Islamo (nors visgi nacionalinę) valstybę iš griuvėsių, likusių Irake po Huseino; vèliau, po JAV okupacijos, dešimtmečio pabaigoje jis išgyveno letargo laikotarpi, o Arabų pavasariui pasibaigus jo reikšmė Artimụjų Rytų regione labai sustiprẻjo, nes vèliau (nuo 2014 m.) jis kontroliavo sausumos ruožus - teritorijas, kadaise priklausiusias dviem buvusioms kolonijinèms nacionalinèms valstybèms - Irako Respublikai ir Sirijos Arabų Respublikai. Saltman ir Winter ịrodinejja, kad „nepaisant to, jog IV valdoma teritorija yra reikšminga, tai nèra svarbiausias dalykas. Kur kas labiau stebina tai, kad IV yra valstybè de facto. Jos veiksmai yra aiškiai matomi; ji siekia gyventojų legitimaticijos ir tam tikru mastu ją turi. “4 Yra ir kitų autorių, pripažįstančių IV dedamas pastangas ịsteigti savo valstybę.

\footnotetext{
${ }^{3}$ Autorius dèkoja dviem anoniminiams recenzentams už ankstesnès straipsnio versijos griežtą kritiką, kuri paskatino dar labiau ịsigilinti ị Islamiškos khilafos valstybės kūrimo pastangų problemą ir čia pristatyti dar daugiau šio proceso apraiškų.

${ }^{4}$ Saltman E.M., Winter Ch. (2014) Islamic State: The Changing Face of Modern Jihadism, Quilliam Foundation, p. 31-32, https://www.quilliamfoundation.org/wp/wp-content/uploads/publications/free/islamicstate-the-changing-face-of-modern-jihadism.pdf, 2017-01-24.
} 
Šiuo metu tai pastebi ir net pripažįsta daugybè mokslininkų ir apžvalgininkų; galima paminèti keletą jų, pavyzdžiui, Shany ir kt., Cronin, le Dret, BelangerMcMurdo, Bernstein, Günther ir Kaden 5 .

Paprastai šie mokslininkai ir apžvalgininkai palaiko keturis pagrindinius teisinius valstybingumo kriterijus, ịtvirtintus $1933 \mathrm{~m}$. Montevideo konvencijoje dèl valstybių teisių ir pareigų ${ }^{6}:$ 1) valstybe turi turèti nuolatinius gyventojus, 2) apibrèžtą teritoriją, 3) vyriausybę ir 4) gebeijima užmegzti santykius su kitomis valstybèmis. Nors per pastaruosius penkerius metus IKV sèkmè gerokai kito, egzistuoja sąlyginis susitarimas ${ }^{7}$, kad IKV iš principo atitinka šiuos kriterijus. Be to, Konvencijos 3 straipsnyje numatyta, kad „Valstybe politiškai egzistuoja nepriklausomai nuo to, ar ją pripažįsta kitos valstybès. Valstybe், net prieš ją pripažįstant, turi teisę ginti savo vientisumą ir nepriklausomybę, užtikrinti savo apsaugą ir gerovę, ir dèl to tvarkyti savo reikalus kaip mano tinkama, priimti ịstatymus pagal savo poreikius, valdyti savo institucijas ir apibrežti savo teismų jurisdikciją bei kompetenciją. ${ }^{\text {"8 }}$

Kadangi šiuo straipsniu nesiekiama išnagrinèti IKV kaip valstybès galimumo ir juo labiau jos legitimacijos, bendra IKV bandymų suformuoti savo valstybę apžvalga skirta tik atskleisti kintančias pilietybės ir nacijos sampratas bei prigimtį. Anot autoriaus, nacijos aspektas turi pridètinę vertę, nes populiariose diskusijose apie IKV prigimtị mažai dėmesio skiriama nacijos kūrimosi ir jos piliečių aspektui.

\footnotetext{
${ }^{5}$ Shany Y., Cohen A., Mimran T. (2014) ISIS: Is the Islamic State Really a State?, The Israel Democracy Institute. http://en.idi.org.il/analysis/articles/isis-is-the-islamic-state-really-a-state/, 2017-01-23; Cronin A.K. (2015) "ISIS Is Not a Terrorist Group", Foreign Affairs, March/April 2015, https://www.foreignaffairs. com/articles/middle-east/isis-not-terrorist-group, 2017-01-23; le Dret V.P. (2015) "International Law: An Analysis of the Montevideo Convention and ISIS's Statehood Claim", Affairs Today, http://affairstoday.co.uk/analysis-of-the-montevideo-convention-and-isiss-statehood-claim/, 2017-01-23; BelangerMcMurdo A. (2015) “A Fight for Statehood? ISIS and Its Quest for Political Domination", http://www.e-ir. info/2015/10/05/a-fight-for-statehood-isis-and-its-quest-for-political-domination/, 201701-23; Bernstein E. (2015) “Is The Islamic State A 'State' In International Law?", https://www.academia.edu/17570619/ Is_the_Islamic_State_a_State_in_International_Law, 2017-01-20; Günther Ch., Kaden T. (2016) The Authority of the Islamic State, Max Planck Institute for Social Anthropology Working Papers 169, https:// www.eth.mpg.de/pubs/wps/pdf/mpi-eth-working-paper-0169, 2017-01-20.

${ }^{6}$ Montevideo Convention on the Rights and Duties of States, 1933, https://www.ilsa.org/jessup/jessup15/ Montevideo\%20Convention.pdf, 2017-01-19.

${ }^{7}$ Saltman E.M., Winter Ch. (2014) Islamic State: The Changing Face of Modern Jihadism, Quilliam Foundation, https://www.quilliamfoundation.org/wp/wp-content/uploads/publications/free/islamic-state-thechanging-face-of-modern-jihadism.pdf, 2017-01-24; Shany Y., Cohen A., Mimran T. (2014) ISIS: Is the Islamic State Really a State?, The Israel Democracy Institute. http://en.idi.org.il/analysis/articles/isis-isthe-islamic-state-really-a-state/, 2017-01-23; Cronin A.K. (2015) "ISIS Is Not a Terrorist Group", Foreign Affairs, March/April 2015, https://www.foreignaffairs.com/articles/middle-east/isis-not-terrorist-group, 2017-01-23.

${ }^{8}$ Montevideo Convention on the Rights and Duties of States, 1933, https://www.ilsa.org/jessup/jessup15/ Montevideo\%20Convention.pdf, 2017-01-19.
} 
Tarp šešių ir dešimties milijonų žmonų - ịvairūs šaltiniai pateikia skirtingus duomenis - apgyvendintų teritorijų ilgalaikẻ kontrolè igalino IV lyderius veikti kaip vyriausybę. Itvyko simboliška permaina, kai buvo paskelbta, kad „Islamo valstybë“ tapo kalifatu - politine sistema, atpažįstama anksčiau egzistavusiuose (nors dažnai mistifikuotuose) arabų kalifatuose 9 . Taigi po dešimtmečio nuo jos ịkūrimo, IV išaugo iš partizaninio karo kovotojų (glaudžiai besilaikančių „al Kaidos“ ideologijos ir naudojančių teroristines taktikas) grupès ị valstybę, kuri tikriausiai atitinka keturis pagrindinius valstybingumo kriterijus, nustatytus Montevideo konvencijoje. Trumpai juos apžvelkime.

Vyriausybè. Galètume pradèti nuo vyriausybès. Tačiau ne tik individų ar jų grupès, besiskelbiančių vyriausybe, buvimas suponuoja vyriausybiškumą - jie turi turèti valdžios monopolị teritorijoje, kurią jie pretenduoja valdyti; kitaip ji žlugtų, negalètų funkcionuoti. Valdžios monopolis - nežiūrint ị tai, kad jo legitimacija gali kilti iš socialinio kontrakto tarp valdančiųjų ir valdomųjų - neišvengiamai apima jègos struktūras, pradedant policijos pajègomis, slaptosiomis tarnybomis, teismais, sienos apsauga, baigiant ginkluotosiomis pajegomis. Kitos ginkluotos grupuotès turi būti nuslopintos, o ịstatymus pažeidę nusikaltèliai - patraukti baudžiamojon atsakomybèn.

IKV yra valstybè ne tik todèl, kad jai vadovaujantys lyderiai viešai paskelbė jos egzistavimą ir geležiniu kumščiu valdo teritoriją ir jos gyventojus, bet pirmiausia todèl, kad ji funkcionuoja kaip vyriausybè ${ }^{10}$. Akivaizdu, kad IKV lyderiai buvo įsitikinę, kad Vakarų Irake ir Rytų Sirijoje esančių teritorijų užgrobimas buvo tik pirmasis žingsnis būsimoje istorijoje naujai kuriant, ši kartą, amžiną ir tvirtą kalifatą. Todèl, kitų neturètų stebinti jos pradinis etapas veikti kaip vyriausybė. Valstybė (daugiau vyriausybè) turi turèti atitinkamas valstybines institucijas (ministerijas ar departamentus). Net Talibano valdomas Islamiškasis Afganistano Emyratas apsimete turịs tokias institucijas.

Atrodo, kad IKV turi gana panašią ị šiuolaikinių valstybių administracinę struktūrą ${ }^{11}$. Ir šioms administracinèms struktūroms pavesta užduotis kuruoti atitinkamas veiklos sritis: ekonomikos, sveikatos priežiūros, socialinès apsaugos ir t. t. Pavyzdžiui, dideliuose miestuose IKV iš tiesų valdo (kitas klausimas, ar gerai) švietimo ir sveikatos priežiūros ịstaigas, užtikrina infrastruktūros paslaugas, sanitarinès higienos priemones, šiukšlių surinkimą, vadovauja

\footnotetext{
${ }^{9}$ Kennedy H. (2016) Caliphate: The History of an Idea, Basic Books.

${ }^{10}$ Alkhouri L., Kassirer A. (2015), Governing The Caliphate: The Islamic State Picture, https://www.ctc. usma.edu/?p=35830, 2016-11-14.

${ }^{11}$ Aoude S. (2014) “The State of Things to Some: The Statehood of ISIS between Practice, International Law, and Religion, p. 6-9, https://www.academia.edu/9951214/The_Statehood_of_ISIS_between_practice_international_law_and_religion, 2017-01-24.
} 
atliekų tvarkymo kompanijoms, kuriose dirba jos samdomi darbuotojai ${ }^{12}$. Tokiu būdu IKV turi gana didelị valstybinį sektorių ir valstybės tarnautojų masę, primenančių bet kurioje dabartinėje valstybëje egzistuojančias. Tiesa, didelè dalis infrastruktūros ir jos darbuotojai paprasčiausiai buvo pagrobti iš Irako ir Sirijos buvusių valstybių. Šiuo atžvilgiu tiek IKV gyvavimo pradinis taškas, tiek jos požiūris ị valstybès formavimąsi labai skiriasi nuo vyraujančio Talibane, kuris paveldèjo šalị su neišvystyta infrastruktūra ir be kompetentingų valstybès tarnautojų. Taip pat IKV požiūris kontrastuoja su „al Kaidos“ pozicija dèl valstybès kūrimo, kurio „al Kaida“ visada vengdavo, net savo kontroliuojamose teritorijose.

Žiūrint vakarietišku liberaliu postreliginiu žvilgsniu, IKV ịstatymai yra drakoniški. Nekreipiant dèmesio ị tai, kad visi IKV ịstatymai yra susiję su islamu, pagrindinis klausimas yra, ar egzistuoja teisès viršenybė (nepaisant ịstatymų griežtumo); tik tada būtų galima kalbèti apie valdžios monopolị. Ir šiuo požiūriu IKV pateisina lūkesčius. Nors teisès viršenybė - o ypač tada, kai ịstatymai akivaizdžiai pažeidžia visuotines žmogaus teises - pati nelegitimizuoja valstybės ir jos santvarkos, pasitelkiant valdžios monopolio kriterijų galima kalbèti apie pagrindinị valstybingumo požymị turintị teritorinị vienetą. Šia prasme, Talibano valdomas Islamiškasis Afganistano Emyratas arba Raudonųjų khmerų (su kuriais Schmid ${ }^{13}$ lygina IKV) valdoma Kampučija, nekalbant apie TSRS arba Trečiajji reichą, buvo valstybès, nors ir su žiauriais režimais. IKV režimas papildo šią ilgą panašaus pobūdžio režimų eilę.

Galiausiai - vyriausybè turi turèti ideologinị pagrindą, reikalingą valstybės valdymo vizijai igyvendinti, tai yra tai, kuo ji skiriasi nuo nusikalstamų grupuočių, kontroliuojančiu (kartais gana dideles) miestų konglomeratų dalis, kai kuriuose pasaulio metropoliuose arba net rajonuose (pvz., narkotikų karteliai Centrinëje ir Lotynų Amerikoje). Šalia valdžios monopolio, IKV taip pat turi ir ideologinę bazę (kuri, reikia pripažinti, yra totalitarinè). Ir būtent tuo skiriasi „al Kaida“ ir IV: kol „al Kaida“ nuolatos atidèdavo kalifato steigimą dèl jos manymu svarbesnio užsièmimo - pasaulinio džihado prieš besibraunantị netikèli „tolimą priešą - „kryžiuočių-sionistų“ aljansą (kalbant Usamos bin Ladino žargonu), IV nusprendè „atkurti“ pirmąją Muchamado valstybę Jasribe (Medinoje) nesėkmingų bandymų ịsteigti musulmonų nacionalines vals-

\footnotetext{
${ }^{12}$ Dreazen Y. (2014) "From Electricity to Sewage, U.S. Intelligence Says the Islamic State Is Fast Learning How to Run a Country", Foreign Policy, http://foreignpolicy.com/2014/08/19/from-electricity-to-sewage-us-intelligence-says-the-islamic-state-is-fast-learning-how-to-run-a-country/, 2017-01-20.

${ }^{13}$ Schmid A.P. (2015) "Challenging the Narrative of the "Islamic State", ICCT Research Paper, p. 1, https:// www.icct.nl/wp-content/uploads/2015/06/ICCT-Schmid-Challenging-the-Narrative-of-the-Islamic-StateJune2015.pdf, 2017-01-24.
} 
tybes (tariamai valdomas atskalūnų - nacionalinių vyriausybių, kurios, anot IV ir jos šalininkų, tarnavo „tolimo priešo“ arba savo interesams, o jie vis vien buvo traktuojami kaip nemusulmoniški ir netgi antimusulmoniški) sąskaita ${ }^{14}$. Valstybingumui IKV suteikia pirmenybę prieš džihadą, o pats džihadas yra ittrauktas ị valstybès kūrimo projektą.

Teritorija. Šio esminio valstybingumo kriterijaus turi būti laikomasi, bent jau atsižvelgiant ị esančias aplink de facto sostinę, Raką, teritorijas, kurios kadaise priklausė rytinei Sirijos daliai ir kurias (straipsnio rašymo metu - $2017 \mathrm{~m}$. vasarị) IKV valde jau trejus metus. Nepaisant to, kad IKV neturi nuolatinių nustatytu sienų, Shany ir kt. ịrodinejja, jog jos „nebūtinai reikalingos teritorijai pripažinti, pavyzdžiui, kai buvo įsteigta Izraelio valstybè, jos sienos nebuvo tiksliai apibrezžtos, dèl kurių lyg šiolei kyla ginčų. Tačiau pagal tarptautinę teisę tai neatèmè iš Izraelio valstybès teisinio statuso. ${ }^{\text {"15 }}$

Tarptautiniai santykiai. Gebejjimas užmegzti santykius su kitomis valstybèmis yra ịtvirtintas Montevideo konvencijoje. Tačiau Shany ir kt. teigia, kad „gebejjimas užmegzti santykius su kitomis valstybėmis, regis, nèra svarbiausias valstybingumo reikalavimas, numatytas Montevideo konvencijoje. Šis kriterijus siejamas su teritorinio subjekto gebẻjimu plètoti užsienio santykius - tai nebūtinai reiškia, kad kitos valstybès nutaria palaikyti su šiuo subjektu diplomatinius, ekonominius ar kitus ryšius. Kitaip tariant, daugumos pasaulio šalių nepripažịstama valstybė visgi gali teoriškai atitikti šį valstybingumo kriterijų. " ${ }^{16}$

Galima užtikrinti, kad IKV nesiekia ir neturètų siekti JT narystès dèl paprastos priežasties - ji nenorètų įteisinti savo valstybės įstodama ị JT, narystę kurioje IKV laiko diskreditacija ar netgi pralaimejjimu ir apskritai neigia JT legitimumą. Tačiau, žinoma, nepriklausymas JT narystei neneigia valstybingumo egzistavimo, pavyzdžiui, Šveicarijos atveju. IKV nesuinteresuotumas nei JT naryste, nei aljansais, nei bet kuria tarptautine organizacija labai skiriasi nuo šiais laikais besiformuojančių (nacionalinių) valstybių požiūrio ị valstybingumą ir jos pripažinimą, kurio per pastaruosius dešimtmečius siekia naujai ịkurtos valstybès. Šiuo atžvilgiu, IKV yra postmoderni (ir postnacionaliné - tai bus nagrinejjama kituose šio straipsnio skyriuose) valstybè. Taip pat ji yra ir ikimoderni valstybè, kadangi ji pareiškia teisę ị kalifato, kaip politinès sistemos, ịkūrimą.

\footnotetext{
${ }^{14}$ Bunzel C. (2015) From Paper State to Caliphate: The Ideology of the Islamic State, Analysis paper No. 19, The Brookings Institution, https://www.brookings.edu/wp-content/uploads/2016/06/The-ideology-of-theIslamic-State.pdf, 2016-11-14.

${ }^{15}$ Shany Y., Cohen A., Mimran T. (2014) ISIS: Is the Islamic State Really a State?, The Israel Democracy Institute. http://en.idi.org.il/analysis/articles/isis-is-the-islamic-state-really-a-state/, 2017-01-23. ${ }^{16}$ Shany Y., Cohen A., Mimran T. (2014) ISIS: Is the Islamic State Really a State?, The Israel Democracy Institute. http://en.idi.org.il/analysis/articles/isis-is-the-islamic-state-really-a-state/, 2017-01-23.
} 
Gyventojai. Montevideo konvencijoje numatytas paskutinis valstybingumo požymis - nuolatiniai gyventojai, be kurių valstybè tikrai negalètų egzistuoti, nes pati vyriausybė, kurią sudaro žmonès (t. y. visuomenès atstovai), netektų prasmès be jos valdomų gyventojų. Tačiau piliečių prasme gyventojų ir nacijos sampratos nebūtinai visada sutampa. Kaip jau buvo minèta, IKV gyventojų skaičius vienu momentu būtų galejjęs pasiekti dešimt milijonų. Tačiau neaišku, kiek iš jų tapatino save su IKV ir kiek laikè save jos nacija / piliečiais.

\section{Pilietybė ir piliečiai... islamiškoje khilafos valstybėje}

Islamiškai khilafos valstybei dalyvaujant savo valstybès kūrime būtini piliečiai, kad ir kaip juos pavadintume, kad ir kaip jie būtų traktuojami ir paskirstyti. IKV gyventojus galima susiskirstyti ị dvi kategorijas: autochtonų (buvusių Irako ir Sirijos piliečių), sudarančių daugumą, ir imigrantų (arabų kalboje - muhadžirūn), kurie, kalbant Vakarų šalių žargonu, yra bene visuotinai laikomi „užsienio kovotojais“. Apskaičiuota, kad trečiujų šalių piliečių, persikrausčiusių $\mathfrak{i}$ IKV arba jos šalininkų valdomas teritorijas, skaičius sieke 30 tūkst. ${ }^{17}$ Jie ir yra šio straipsnio tyrimo objektas, nes būtent imigrantai išryškino IKV atvejo unikalumą, atsižvelgiant ị kintančią pilietybès sampratą ir jos padarinius pasauliui, o ypač Europai. Beje, būtent jie pavertė IKV postnacionaline (nes IKV nepaiso socialinio kontrakto principu, kuriais remiantis kuriamos šiuolaikinès nacijos ir šalys) ir ikimodernia (antinacionaline, nes ji atgaivina klasikinę islamo sampratą apie valstybę ir jos piliečius).

Žinoma, IKV piliečių samprata yra kitokia (ne klasikinė), kadangi IKV neišduoda asmens tapatybę patvirtinančių dokumentų, leidžiančių asmeniui keliauti ị užsienị. Tačiau būta nepatvirtintų pranešimų, kad IKV pradejo išdavinèti pasus iš karto po to, kai ji paskelbẻ kurianti suverenią valstybę ${ }^{18}$. IKV pilietybẻ ir jos piliečiai yra daugiau dvasinio pobūdžio (arba „virtuali pilietybe்“) ir šiuo atžvilgiu IKV pilietybè yra postmodernus socialinis reiškinys.

IKV, kaip postnacionalinè valstybe், nepripažista arabų „tautų“ kolonijinio palikimo - ji neišskiria Sirijos, Irako, Jordanijos ir Saudo Arabijos gyventojų. Pranešta, kad kalifu pasiskelbęs Abu Bakras al Baghdadis pasake: „[Ji] „Is-

\footnotetext{
${ }^{17}$ The Soufan Group (2015) Foreign Fighters: An Updated Assessment of the Flow of Foreign Fighters into Syria and Iraq, http://soufangroup.com/wp-content/uploads/2015/12/TSG_ForeignFightersUpdate3.pdf, 2017-01-23.

${ }^{18}$ al-Arabiya (2014) “ISIS Allegedly Issues 'caliphate’ Passport", http://english.alarabiya.net/en/News/middle-east/2014/07/05/ISIS-allegedly-issues-caliphate-passport.html.http://www.nytimes.com/2014/06/11/ world/middleeast/militants-in-mosul.html, 2017-01-24.
} 
lamo valstybë“ nepripažista nei valstybès dirbtinių sienų, nei bet kurios kitos pilietybès, išskyrus savo valstybès pilietybę. ${ }^{19}$ Be to, IKV vaizduoja save kaip jos piliečių priklausymą etninei grupei ignoruojančią valstybę. Nepalyginamai svarbus jai yra religinis tapatumas - IKV naciją gali sudaryti tik tikintys (kad ir kaip juos traktuotų IKV vyriausybè) musulmonai, tradicinio musulmonu viseto (umos) atitikmuo. Tačiau, nepaisant to, kad hipotetiškai visi pasaulio musulmonai gali tapti IKV nacijos atstovais (tokiu atveju IKV nacija sutaptų su visuotine uma), iki šiolei savo piliečiais IKV laikẻ tik tuos, kurie sąmoningai nustatę su ja ryšị. IKV pasakytų, kad tik patys geriausi iš umos jau yra tapę jos piliečiais; žinoma, tai yra griežtai ginčijama tų musulmonų, kurie nesilaiko IKV ideologijos.

IKV pilietybès igyvendinimo klausimas tiesiogiai siejamas su fiziniu persikèlimu ị kalifato teritoriją, kalbant IKV žargonu, atliekant hidžrą. Skelbdamas islamiškos khilafos valstybès ịkūrimą, al Baghdadis savo garso ịrašo pranešime aiškiai skatina viso pasaulio musulmonus atlikti hidžrą: „O! Viso pasaulio musulmonai! Kas gali emigruoti $\mathfrak{i}$ „Islamo valstybę“, leiskime jiems tai padaryti. Nes emigracija ị islamo erdvę - privaloma. ${ }^{20}$ Šis šūkis atsispindi intensyviai propaguojant hidžrą "Islamo valstybès“ oficialaus žurnalo Dabiq trečiajame numeryje, išleistame $2014 \mathrm{~m}$. rugpjūti, praẻjus keletui ménesių po to, kai buvo paskelbtas kalifatas. Galima manyti, kad Dabiq atvaizduoja ir paviešina IKV oficialią pilietybès ir natūralizacijos politiką. Iki $2014 \mathrm{~m}$. jau buvo daugybė musulmonų imigrantų, traktuojančiu hidžrą pirmiausia kaip priemonę ịvykdyti džihadą; IKV ịsikūrus, hidžra iggavo naują aspektą - tūkstančiai moterų ir ištisų šeimų skyrè išskirtinị dẻmesị hidžrai atlikti ${ }^{21}$. Kitais žodžiais tariant, nors iki to laiko hidžra dèl džihado buvo gerai žinomas reiškinys Irako ir Sirijos teritorijose, IKV atsiradimas ne tik suteike jai naują postūmį, bet ir kardinaliai pakeitė supratimą apie pilietybę.

Hidžros prototipas - Muchamado išsikèlimas $622 \mathrm{~m}$. iš Mekos ị Jasribą. Hidžros raison d'etre yra susijusi su sąmoningu, iš anksto apgalvotu persikèli-

\footnotetext{
${ }^{19}$ Bunzel C. (2015) From Paper State to Caliphate: The Ideology of the Islamic State, Analysis paper No. 19, The Brookings Institution, p. 24, https://www.brookings.edu/wp-content/uploads/2016/06/The-ideologyof-the-Islamic-State.pdf, 2016-11-14.

${ }^{20}$ Bunzel C. (2015) From Paper State to Caliphate: The Ideology of the Islamic State, Analysis paper No. 19, The Brookings Institution, p. 32, https://www.brookings.edu/wp-content/uploads/2016/06/The-ideologyof-the-Islamic-State.pdf, 2016-11-14.

${ }^{21}$ Sherwood H., Laville S., Willsher K., Knight B., French M., Gambino L. (2014) "Schoolgirl jihadis: The female Islamists leaving home to join Isis fighters", The Guardian, https:/www.theguardian.com/ world/2014/sep/29/schoolgirl-jihadis-female-islamists-leaving-home-join-isis-iraq-syria, 2017-01-23; Simsek B., Satter R. (2014) “Turks Leave for 'Family Friendly' IS Group”, Associated Press, http://www. sandiegouniontribune.com/sdut-turks-leave-for-family-friendly-is-group-2014sep24-story,amp.html, 2017-01-24.
} 
mu iš vienos terpès, kurioje žmogus negali visapusiškai igyvendinti islamiško gyvenimo būdo (musulmonų klasikinèje jurisprudencijoje žinomo kaip Dar al-charb), ị tą, kurioje islamas yra visiškai realizuojamas (tokiu atveju - Dar alislam) arba tikimasi sudaryti atitinkamas sąlygas islamui realizuoti. IKV propagandos mechanizmas nuejo toli, ̣tikinèdamas potencialius imigrantus atlikti hidžrą - suvokiamą kaip fard ain, ir kurią privalo atlikti kiekvienas (tikintis) musulmonas, gyvenantis bet kurioje pasaulio dalyje - nes visos IKV, tariamai atgimstančio Dar al-islam, nekontroliuojamos teritorijos yra Dar al-kufr („,netikejjimo buveinë“), nepriklausomai nuo to, ar tai yra šalys, kuriose gyvena musulmonų dauguma arba jų mažuma, ir ar jos buvo musulmonų valdomos. Šia prasme viso pasaulio musulmonai ịsipareigoję atlikti hidžrą, tačiau jų tikslo vieta gali skirtis - nekalbant apie Sirijos ir Irako teritorijas - tai gali būti bet kuri vilaja (provincija), ịtraukiant (bet neapsiribojant): Libiją, Nigeriją, Afganistaną ir tas teritorijas, kuriose yra grupių, davusių priesaiką IKV. Tokiu būdu hidžros klausimas (ir problema) tapo globalios svarbos reikalu.

Yra keletas tipų migrantų (muhadžirūn), kuriems pavyko įsilieti į IKV arba bent jau tokių, kurie dejo pastangas atlikti hidžrą, tačiau buvo sustabdyti teisėsaugos institucijų savo valstybėse arba trečiosiose šalyse. Pirmoji ir labiausiai paplitusi yra anksčiau minèta ,užsienio kovotojų“ kategorija, sudaryta daugiausia iš jaunų vyrų. Nors iš tiesų jų didžioji dauguma hidžrą laiko būdu vykdyti džihadą, kurị jie aiškina vien militaristiniu požiūriu, galima pastebėti, kad ne visi atvykusieji i IKV teritoriją iš tikrųjų tapo „kovotojais“. Pavyzdžiui, trys jauni Latvijos gyventojai (kurie atsivertẻ ị islamo tikejjimą) atliko hidžrą i Vidurio Rytus ${ }^{22}$, tačiau nežinoma, ar jie tikrai tapo „kovotojais“, naudodami ginklus ir stodami ị mūš̨̀.

Bet kuriuo atveju didžioji dalis į IKV teritoriją sugebejjusių patekti vyrų tapo šios valstybės kovotojais. Tačiau remiantis T. Hegghammerio ${ }^{23}$ atlikta musulmonu užsienio kovotojų analize, reikètų susilaikyti nuo atvažiavusiujų iš užsienio šalių vadinimo „teroristais“, nors vadinti juos sukilèliais taip pat būtų nepagrịsta. Kita vertus, fenomenologiniu požiūriu: argi nebūtų tikslinga juos laikyti IKV ginkluotụjų pajègų dalimi ${ }^{24}$, ịtrauktų i̇ mūši prieš kitų šalių (Irako, Sirijos ir Kurdistano) ginkluotąsias pajègas ir nereguliarias ginkluotąsias formuotes? Argi nebūtų pagrịsta visą IKV ginkluotą kovą laikyti „,nepriklausomybès kovų“ išraiška?

\footnotetext{
${ }^{22}$ The Baltic Times (2016) Several Latvians join IS to fight in Syria, 2016-03-07, http://www.baltictimes. com/several_latvians_join_is_to_fight_in_syria/, 2017-01-23.

${ }^{23}$ Hegghammer Th. (2010) "The Rise of Muslim Foreign Fighters: Islam and the Globalization of Jihad", International Security, Vol. 35, No. 3, p. 53-94.

${ }^{24}$ Cronin A.K. (2015) "ISIS Is Not a Terrorist Group", Foreign Affairs, March/April 2015, https://www. foreignaffairs.com/articles/middle-east/isis-not-terrorist-group, 2017-01-23.
} 
Ypač jeigu pripažistame, kad šiose teritorijose gyvenantys arabai sunkiai susitapatina su Irako ir Sirijos postkolonijinèmis nacionalinèmis valstybėmis ir sunitų, gyvenančių pohuseininiame Irake, separatistinès nuotaikos buvo pastebimos ne tik retoriniu lygmeniu, bet ir veiksmuose praktiškai nuo pat amerikiečių Irako okupavimo pradžios ${ }^{25}$. Galiausiai - ar jie nekovoja už suverenią valstybę, kad ir kaip jų pavadintą? Tiesa, šiomis dienomis ji yra apsiausta islamo drabužiu, tačiau jeigu IKV nebeegzistuos, tai savaime nereikš, kad gyventojai norès vèl prisijungti prie Irako ir Sirijos atitinkamai.

Šiame Irako ir Sirijos teritorijose vykstančiu socialinių ir politinių įvykių, kurių pagrindiniai veikẻjai yra autochtoniniai (vietiniai) sunitai, platesniame ir žymiai sudėtingesniame kontekste, atvykstantys muhadžirūn matytini kaip prisideję prie pastangų vietinių gyventojų, kurie ne tik sukūrẻ IKV pirmtakus, bet ir ịsteigė ją pačią. Šiuo atžvilgiu muhadžirūn yra vietinių gyventojų malonèje - bus ar nebus jie pripažinti kaip "natūralizuoti piliečiai“, kuriais tampama ịstojus ị kuriamos valstybės ginkluotąsias pajėgas. Deja, šiuo klausimu nèra atliktų tyrimų, paaiškinančių, kaip „užsienio kovotojai“ yra suvokiami ir priimami vietinių gyventojų IKV teritorijose.

Antra imigrantų kategorija apima jaunas vienišas moteris ${ }^{26}$. Apskaičiuota, kad jos sudaro vieną dešimtąją visų muhadžirū $n^{27}$. IKV neleidžia moterims dalyvauti kovinèse operacijose, tad vertinti jas kaip „užsienio kovotojas“ būtų klaidinga. Kita vertus, galimas dalykas, kad IKV ịtraukia šias moteris ị džihadą per nekovines operacijas, pavyzdžiui, leisdama joms tarnauti IKV pasienyje arba dirbti moralès policijos sergètojomis.

Galiausiai galima išskirti šeimų su vaikais kategoriją, apie kurią tikriausiai yra mažiausiai kalbama, galbūt ne tik dèl to, kad ją sudaro neabejotinai mažesnè muhadžirūn dalis, bet ir dèl tokių atvejų jautraus pobūdžio. Dabiq puslapiuose IKV dažniausiai vaizduojama kaip ideali vieta šeimoms įsikurti ir toks muhadžirūn tipas yra puoselejjamas. Nors vargu ar yra tam tikrų apskaičiavimų - jau nekalbant apie patikimus statistinius duomenis apie atvykusias i IKV šeimas - tačiau yra daug kalbama apie išvažiavusias i IKV šeimas iš

\footnotetext{
${ }^{25}$ International Crisis Group (2013) Make or Break: Iraq's Sunnis and the State, Report 144, https://www. crisisgroup.org/middle-east-north-africa/gulf-and-arabian-peninsula/iraq/make-or-break-iraq-s-sunnisand-state, 2017-01-24.

${ }^{26}$ Rafiq H., Malik N. (2015) Caliphettes: Women and the Appeal of Islamic State, Quilliam Foundation, https://www.quilliamfoundation.org/wp/wp-content/uploads/publications/free/caliphettes-women-andthe-appeal-of-is.pdf, 2016-11-18.

${ }^{27}$ Sherwood H., Laville S., Willsher K., Knight B., French M., Gambino L. (2014) "Schoolgirl jihadis: The female Islamists leaving home to join Isis fighters", The Guardian, https://www.theguardian.com/ world/2014/sep/29/schoolgirl-jihadis-female-islamists-leaving-home-join-isis-iraq-syria, 2017-01-23.
} 
Jungtinès Karalystès ir keleto kitu šalių ${ }^{28}$. Žinoma, kad bent jau viena šeima (kurioje ị islamą atsivertę abu tèvai) buvo atlikusi hidžrą tiek iš Estijos ${ }^{29}$, tiek iš Latvijos ${ }^{30}$.

Nors tarp muhadžirūn gali būti ganètinai daug pragmatikų ir nuotykių ieškotojų - nuvykusiu i $\mathrm{i}$ IKV ne religiniais ar ideologiniais sumetimais, bet dèl kitų priežasčiu - ir jų judejjimą galima traktuoti kaip hidžrą tam tikra to žodžio prasme, didžioji dauguma moterų tikriausiai leidosi ị pavojingą kelionę dèl religinių įsitikinimų, tikèdamosis rasti jei ne rojų žemèje, tai bent pačią autentiškiausią islamišką terpę. Turbūt didelè dalis šeimų taip pat turejjo šių lūkesčių, sustiprintų tiek nepaliaujamos IKV propagandos, realizuojamos prašmatniuose internetiniuose žurnaluose, pavyzdžiui, Dabiq (anglų kalba), Vostok (rusų kalba), Dar al-Islam (prancūzų kalba), tiek sẻkmingai atlikusių hidžrą ir apsigyvenusių (tai pavyko padaryti per socialinius tinklus ir panašiai) IKV teritorijoje moterų. Kokie buvo jų tikri patyrimai (pvz., nesèkmingas integravimasis, kalbos barjeras ir kultūriniai skirtumai, vietinių gyventojų rodoma panieka, galimas rasizmas ir t. t.) yra visiškai kitas klausimas. Tačiau bet kuriuo atveju kalbant apie dabartinius migracijos procesus Vidurio Rytuose ir aplink juos, galima pastebèti ne tik išeivių, bet ir ateivių (nors jų skaičius išties daug mažesnis) srautus ir iš to kylančias pasekmes ir priimančiajai šaliai (šiuo atveju tai yra IKV vietiniai gyventojai), ir patiems imigrantams (muhadžirūn).

Yra keletas natūralizacijos būdų. Vienas iš jų - atlikti karo tarnybą šalyje. JAV ịgyvendina būtent tokị natūralizacijos metodą - i JAV kariuomenę i̊stojęs užsienio valstybès pilietis gali tikètis greitesnio pilietybės suteikimo. Kitas būdas apima glaudžius šeimos ryšius, pavyzdžiui, imigrantui sutuoktiniui pilietybè gali būti suteikiama lengviau.

Pagrindinis natūralizacijos kriterijus IKV - duoti priesaiką kalifui, kitais žodžiais tariant, bet kuris asmuo, parodęs ištikimybę IKV ideologijai (arba jos griežtai laikęsis), gali tapti šios valstybès piliečiu. Tarnaujantys IKV ginkluotosiose pajègose natūraliai tampa jos piliečiais, nes būtent jų stojimas i šias pajègas laikomas lojalumu valstybingumo formavimuisi. Taigi „užsienio ko-

\footnotetext{
${ }^{28}$ Sherwood H., Laville S., Willsher K., Knight B., French M., Gambino L. (2014) "Schoolgirl jihadis: The female Islamists leaving home to join Isis fighters", The Guardian, https://www.theguardian.com/ world/2014/sep/29/schoolgirl-jihadis-female-islamists-leaving-home-join-isis-iraq-syria, 2017-01-23; Dutch News (2014) “Two more Dutch families head for Syria, taking their children", 6 September 2014, http://www.dutchnews.nl/news/archives/2014/09/two_more_dutch_families_head_f/, 2017-01-24. ${ }^{29}$ Roonemaa H. (2015) "Estonian man converted to Islam and went to fight with ISIS in Syria", Delfi.ee, 22 January 2015, http://www.delfi.ee/news/en/news/estonian-man-converted-to-islam-and-went-to-fightwith-isis-in-syria?id=70620007, 2017-01-23.

${ }^{30}$ Security Police of Latvia (2016) Annual Report 2015, p. 21, www.dp.gov.lv/en/?rt=documents\&ac=down load\&id=15, 2017-01-23.
} 
votojų“ apibrèžimas yra nebeaktualus ir netinkamas kalbant apie IKV - IKV nẻra užsienio kovotojų, bet tik šalies ginkluotosiose pajègose tarnaujantys natūralizuoti muhadžirūn. Tai iš esmès neturi ryšio su „užsienio kovotojais“, kariaujančiais daugybès nereguliarių ginkluotų grupuočių arba Irako ir Sirijos režimų pusèje, nes jie nesusitapatina su jokia valstybe arba teritoriniu vienetu kovinès operacijos zonoje, bet labiau identifikuoja save su konkrečia ginkluota grupuote.

Nepaisant to, kad dauguma natūralizuotų IKV piliečių išlaiko savo pradinę pilietybę (nors kai kurie iš jų viešai sunaikino savo pasus), tai nèra svarbu IKV - ji nepripažįsta kitų valstybių teisètais subjektais ir, kaip buvo anksčiau minèta, priima tik „islamo pilietybę“. Antra vertus, kai kurių šalių gyventojų pasai (ir juose nurodyta pilietybė) virsta vertingais arba naudojami kaip priemonè, leidžianti IKV piliečiams judeti laisvai po visą pasaulị ir dalyvauti kovinèse operacijose.

Siekiant užkirsti kelią natūralizuotiems IKV piliečiams grižti ị savo kilmès šalis, kai kurios valstybės pradejjo svarstyti galimybę atimti iš IKV piliečių jų pradinę pilietybę - tai nuspręstų muhadžirūn kaip IKV ir tik IKV piliečių likimą. IKV žlugus, tokie žmonès, kuriuos jų valstybės oficialiai laiko teroristais, galètų atsidurti keblioje savo teisinio statuso neapibrě̌tumo padėtyje. Tai būtų dar vienas reikšmingas pilietybès sampratos vystymosi (ir ypač piliečių apsaugos supratimo) aspektas.

Galimybè tapti IKV piliečiu - net jam iš esmès neįžengus i jos teritoriją - daro ją unikalią ir postmodernią. Žmogui užtenka tik duoti priesaiką jos alifui. Tokiu būdu IKV turi „provincijas“, gerokai nutolusias nuo jos pagrindinès teritorijos rytų Sirijoje ir vakarų Irake. Šios provincijos apima žemės plotus, tariamai kontroliuojamus kalifo arba jo vardu Šiaurès ir Vakarų Afrikoje, Centrinėje ir Pietinėje Azijoje - manoma, kad šių regionų gyventojai yra IKV piliečiai, tačiau nežinoma, kiek iš jų laiko save IKV piliečiais arba apskritai kiek supranta apie tai. Analogiškai, galimas dalykas, kad Europoje gyvenantys musulmonai, kurie galbūt net nebuvo išvažiavę iš savo gimtojo krašto, bet (ne būtinai viešai) buvo prisiekę ištikimybę kalifui Abū Bakrui, tapo IKV „natūralizuotais nereziduojančiais piliečiais“. Jų skaičius gali būti didesnis negu bent jau bandžiusių atlikti hidžrą. Kitaip tariant, „dvasinių muhadžirūn“ skaičius galimai gerokai pralenkia „fizinių muhadžirūn“. Europos šalys tam neteikia didelès reikšmès - svarbu pabrèžti, šis naujas piliečių ir jų priklausymo nacijai ir valstybei suvokimas pastebimas Europoje ir kelia daugybę iššūkių. 


\section{Iššūkiai Europai}

Apskaičiuota, kad vien Rusija „eksportavo“ apie tris tūkstančius muhadžirūn. Kartu su europiečiais šis skaičius siekia daugiau nei dešimt tūkstančiu žmonių, atlikusių hidžrą i Vidurio Rytus nuo 2012 m. - pirmiausia, be abejonės, $\mathfrak{i}$ IKV kontroliuojamas teritorijas. Žinoma, dalis jų mire (buvo nužudyti) ir patvirtinimai buvo išsiųsti i jų tėvynes. Kasdien augant tikimybei, kad IKV jos priešininkų pajègų bus greitu laiku sužlugdyta, šių IKV natūralizuotų piliečių padètis tampa labai nesaugi. Nors dauguma jų - būtent tarnaujančių IKV ginkluotosiose pajègose - bus nužudyti mūšio lauke arba pergalę pasiekusios kovojančios pusès kalèjime, didžioji dalis likusių gyvų bus „deportuoti“ i Europos šalis). Ir štai čia galima susidurti su didžiuliais iššūkiais.

Iki 2015 m. didžioji dalis Europos šalių vienu ar kitu būdu laikè hidžrą i IKV, ir konkrečiai IKV pilietybès prièmimą, nusikaltimu, o kai kurios šalys, pasisakiusios už patraukimą baudžiamojon atsakomybẻn, taip pat svarsto galimybę atimti iš muhadžirūn pilietybę. Tiesa, šis būdas - už hidžrą i IKV patraukimas baudžiamojon atsakomybèn - tik likviduoja minètų veiksmų padarinius, bet nesprendžia klausimo, kodèl europiečiai norètų, pirma, atsisakyti europinès pilietybès kartu su europine tapatybe, antra, pasirinkti naujai atrastą musulmonišką tapatybę ir pilietybę. Taigi nors tam tikrais atvejais hidžros patraukimas baudžiamojon atsakomybèn gali būti laikomas atgrasimo priemone, tačiau daugeliu atvejų tai tik igalina hidžrą atlikti slaptai. Kitaip tariant, tokie veiksmai nepašalina pagrindinių priežasčių. Todèl žlugus IKV vis tiek būtų ieškoma galimybès pasirinkti „musulmonišką pilietybę“ (ịsivaizduojamą pilietybę), kurią suteike IKV. Taigi, hidžros iššūkiai tikrai išliks ir IKV nustojus egzistuoti.

Sulaikytiems atvykusiems iš IKV muhadžirūn - pvz., vienam iš Latvijos, dviem musulmonams iš Estijos, keturiems čečènams Lenkijoje, tūkstančiui kitų visoje Europoje - buvo pateikti kaltinimai dèl ịstojimo ị teroristines organizacijas arba joms teikiamos paramos. „Deportuotiems“ muhadžirūn grižus, patrauktų baudžiamojon atsakomybėn skaičius smarkiai išaugtų, o kai kuriose šalyse iki dešimties kartų. Tarnavusių IKV ginkluotosiose pajegose atveju baudžiamasis persekiojimas gali būti vykdomas viešai ir greitai, o moterų ir vaikų - nebus toks sklandus; tai tapo akivaizdu, kai žmonės, noredami išvykti į IKV teritorijas, buvo sulaikyti.

Nepaisant to, kad muhadžirūn susidurs su teisinèmis pasekmèmis hidžros kriminalizacijos atveju, jų socialinè diskriminacija, jau pastebima šalyse, kuriose sugrịžę arba deportuoti muhadžirūn buvo patraukti ị teismą, bus 
Europai didesnis iššūkis. Vietinejje spaudoje yra daug šališkų ataskaitų apie šiuos žmones ir bendrai su islamu ir musulmonais susijusius įvykius, kuriuose ịtariamieji išreiškia simpatiją IKV ir jos ideologijai ir dèl to yra laikomi tiesioginiu pavojumi arba „ateiviais“, nepriklausančiais Europos kultūrinei terpei ir joje negyvenančiais. Todèl yra didelè rizika, kad buvę muhadžirūn, paleisti iš kalëjimo, susidurtų su marginalizacija ir diskriminacija, o tai neišvengiamai pastūmètų juos nuo visuomenès vèl ị radikalių grupuočių rankas.

Laikant muhadžirūn ir kitus Europoje gyvenančius musulmonus iš esmès skirtingais nuo nemusulmonų, skatinama segregacija, rasizmas, šovinizmas ir ksenofobija. Tačiau didesnę dalị muhadžirūn ir musulmonų diskriminacijos suponuoja paplitusi „muslimofobija ${ }^{\text {“31 }}$ (šiuolaikinio orientalizmo ${ }^{32}$ forma), kuri prasismelkè ị visą Europos visuomenę ir vis didẻja pastaruosius kelis dešimtmečius. „Muslimofobiškas“ požiūris ir veiksmai ateina iš ịvairių šaltinių - valstybės ir visuomenès segmentų, pavyzdžiui, vyriausybès, politinių partijų, nemusulmonų tikèjimo bendruomenių, neformalių pilietinès visuomenès grupių, žiniasklaidos, švietimo sistemos (vadovèlių) ir netgi menų.

„Muslimofobija“ savo apraiškomis yra viena iš Europos musulmonų radikalizacijos tiesioginių priežasčių, pasitelkiant daugybę Europoje gyvenančių musulmonų (imigrantų ir ị islamą atsivertusių žmonių) liudijimų, bylojančių apie kitos religijos atstovų neigiamą požiūrị ị islamą ir musulmonus, lemiantį žmogaus apsisprendimą tapti (pamaldžiu) musulmonu ir skatinantị radikalizaciją.

Nors muslimofobija gali būti laikoma musulmonų sprendimo veikti radikaliai veiksniu, pati viena ji nesąlygoja šios transformacijos. Greičiau ji stumteli ị apologetyvų izoliacionizmą. Pagrindinès musulmonų radikalizacijos priežastys glūdi giliau negu europiečių neigiamas požiūris ị musulmonus. Europos musulmonų radikalizaciją būtina analizuoti pasitelkus platesnị (pasauliniu mastu) spektrą įvykių, atskleidžiančių religijos vietą žmogaus ir socialiniame (politiniame) gyvenime. Europos musulmonai, kaip ir jų tikejjimo broliai ir seserys, yra vis labiau ịtraukiami ị sūkurị, sukurtą islamo revaivalizmo, ir ypač salafi-džihadi atmainos, pasireiškusios kaip IKV konvulsijos.

Anot mokslininkų ${ }^{33}$, islamo revaivalizmas laikomas reakcija tiek ị musulmonų visuomenių ir valstybès santvarkos modernizavimą, vykstantị nuo XIX amžiaus, tiek i pasenusius procesus, kuriuos patys reviavalizmo atstovai laiko dvasinèmis ir socialinemis deviacijomis - nukrypimu nuo „tikrojo, tyrojo“ islamo. Puoselejjantys tikejjimo atgaivinimą musulmonai siekia įdiegti

\footnotetext{
${ }^{31}$ Erdenir B. (2010) "Islamophobia qua racial discrimination: Muslimophobia", Muslims in 21st Century Europe: Structural and Cultural Perspectives, ed.: Anna Triandafyllidou, Routledge.

${ }^{32}$ Said E. (1978) Orientalism, Penguin books.

${ }^{33}$ Demant P.R. (2006) Islam vs. Islamism: The Dilemma of the Muslim World, Praeger.
} 
(arba atkurti) holistinę islamišką sistemą, valdančią ịsivaizduojamos islamiškos santvarkos piliečių visuomeninį ir asmeninį gyvenimą. Nepaisant to, kad dauguma revaivalizmo atstovų yra taikūs ir tiki neprievartine reislamizacija, mažuma - nekantrūs žmonès, manantys, kad agresyvesnès priemonès, ịskaitant valstybės struktūros uzurpavimą panaudojus ginklą, bus tinkamesnės.

Iki XXI amžiaus islamo revaivalizmas tapo visuotiniu reiškiniu, sustiprintu, be kita ko, greitai besikeičiančių informacinių technologijų, platinančių akimirksniu informaciją ir idejjas daugybei „sąmoningų“ žmonių, tarp jų Europos gyventojams. Europos musulmonams per IKV internetinę žiniasklaidą paskelbtas pranešimas buvo labai patrauklus. Perskaitę IKV propagandos tekstus, didžioji dalis Europoje gyvenančių musulmonų jautėsi arba pradejo jaustis esą ne savo vietoje Europoje, kadangi jų dvasiniai poreikiai tikriausiai nebuvo patenkinti arba, dar blogiau, Europos visuomenių ir valstybių socialinè ir politinè sandara ignoravo juos. Veiksmingas religijos išstūmimas iš Europos visuomenès ir privačių sektorių sukèlè jos gyventojų priešiškumą, įskaitant ir dalị musulmonų, kurie prièmè tai asmeniškai suvokdami, kad iš anksto parengta antiislamiška valstybès santvarka lieka už viso proceso ribų. Kai kurie iš jų nusprendè šiam vyksmui pasipriešinti.

Taigi kai kurių (Europos) musulmonų radikalizacija vertintina per vidinès kovos prizmę pavienių musulmonų, kuriems nepavyko susidoroti (dèl to ir priešinamasi) su pagrindine tendencija, dèl kurios Europos visuomenès (ir jų valstybès) tapo potencialiai postreliginès ir, šių musulmonų nuomone, „naujų barbarų" visuomene, nebeturinčia transcendentinio tikslo. Europa, kaip Dar al-charb, nepaliko šiems musulmonams kito pasirinkimo, kaip tapti muhadžir, jei ne fiziškai, tai bent dvasiškai. Ir kol viltis atlikti hidžrą i ị ịivaizduojamą Dar al-islam gyva, tol, IKV atveju, egzistuos tikimybe, kad kai kurie Europos musulmonai (sieks tapti arba) taps „,natūralizuotais piliečiais“ savo ịsivaizduojamoje „tikrojo“ Dar al-islam realybëje.

\section{Išvados}

IKV valstybingumo projektas tikriausiai yra pasmerktas, tačiau ne dèl jos piliečių uolumo stokos. Visų pirma, taip yra dèl to, kad pagrindinės pasaulio jègos vengia tokio politinio subjekto, kuris kelia klausimą dèl Vestfalijos sistemos, padejusios įsteigti šiuolaikines nacionalines valstybes, egzistavimo. Tačiau tiek jos kaip eksteritorinès valstybès savitos prigimties, tiek jos „dvasinès pilietybès“ atžvilgiu, išstumiant IKV iš Sirijos ir Irako teritorijų nereikštų savaime jos sunaikinimo, kol yra „provincijos“ - kalifatas neturi išskirtinio 
sąlyčio su teritorija (nors, tiesa, Vidurio Rytai turi tam tikrą vietą suvokiant valstybingumą) ir galètų būti „perkeltas“ $\mathfrak{i}$ bet kurią teritoriją, veiksiančią kaip Dar al-islam. Be to, kol yra per visą pasaulį paplitusių IKV piliečių, suvokiamų kaip naujo tipo diaspora, tikètina, kad bus dedamos pastangos (iš naujo) igyti IKV nepriklausomybę, nes kartą iš butelio išleistą kalifato džiną būtų sunku vèl ị ji patalpinti: tai tęsiasi šimtmetị po to, kai Turkijos vyriausybẻ panaikino kalifato instituciją XX amžiaus pradžioje.

Vis dèlto netgi jei kalifatas nebus iš naujo atkurtas bet kokio kito iškart atpažistamo pseudoportreto pavidalu, IKV valstybingumo ir atitinkamai nacionališkumo projektas pakeitè tradicinị valstybès formavimosi, valstybès ir nacijos kūrimosi, migracijos reikšmès, natūralizacijos ir pilietybès suvokimą pasauliniu mastu, ypač Europoje. Politologams rimtai įvertinus IKV kaip valstybingumo projektą, būtina persvarstyti tarptautinius santykius ir geopolitinius procesus pasaulyje.

Kai kurių Europos musulmonų ir pasirinkusių hidžros kelią (nors ir dvasinị) žmonių kintantis piliečio ir jų priklausymo nacijai (tradicinio socialinio kontrakto) suvokimas - IKV žlugimo ir neišvengiamo (priverstinio) grižimo ị savo gimtąsias vietas atveju - iškels naujų iššǔkių, su kuriais jau buvo susidūrusios Europos valstybès. Hidžros kriminalizacija yra viena iš Europos valstybių visuotinai pripažintų atoveiksmių. Tačiau ši kriminalizacija sprendžia padarinius, o ne priežastis. Kai kurių musulmonų radikalizacijos priežastys, iš dalies skatinamos muslimofobijos, lieka neišspręstos.

Todèl artimiausioje ateityje Europos politinio ir intelektualinio elito neadekvatus požiūris $\mathfrak{i}$ IKV, kai šis elitas traktuoja ją vien tik kaip teroristinę grupuotę, o išeivius iš Europos laiko paprastais „užsienio kovotojais“, paskatins plačiau ir nuodugniau išanalizuoti tiek IKV reiškinį, tiek nacijos, valstybès ir pilietybès sampratas, nagrinėjant (pasaulinès postnacionalinès valstybės) pilietybę, IKV pateiktą kaip vieną iš vertingų apsvarstyti alternatyvų. Pandoros skrynia ne tik kad buvo atverta, ji netgi sudaužyta, todèl nèra greitų būdų problemoms spręsti, tačiau yra daugybė potencialių iššūkių, su kuriais, regis, galètume susidurti tik labai tolimoje ateityje arba kuriuos kai kurių Europos šalių vyriausybės tik nuspejja. Tačiau laikyti musulmonus „užsienio kovotojais“ gali būti visiškai klaidinga ir žalinga bet kurios Europos šalies nacionaliniam saugumui, nepriklausomai nuo jų skaičiaus. 